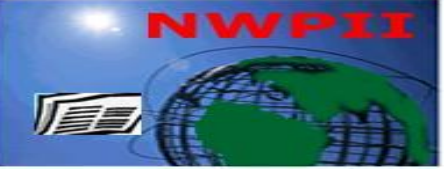

American Journal of Biomedical Sciences

ISSN: 1937-9080

nwpii.com/ajbms

\title{
The Active Metabolite of UTL-5g, 5-Methylisoxazole-3-Carboxylic Acid, is Anti-Inflammatory and Reduces Doxorubicin-Induced Cardiac Toxicity
}

\author{
Yiguan Zhang ${ }^{1,2}$, Yongxin Tang ${ }^{1}$, Ben Chen $^{3}$, Frederick Valeriote ${ }^{2}$, Subhash Gautam ${ }^{2}$, Xiaohua Gao ${ }^{2}$, \\ Jiajiu Shaw ${ }^{2,3, *}$
}

${ }^{1}$ New Phiaring Bio-medical Science Co., Ltd, Chengdu, China

${ }^{2}$ Henry Ford Health System, Internal Medicine, Detroit, Michigan, USA

${ }^{3} 2{ }^{\text {st }}$ Century Therapeutics, Detroit, Michigan, USA

"Corresponding Author

Jiajiu Shaw

$21^{\text {st }}$ Century Therapeutics

440 Burroughs St., Suite 447

Detroit, Michigan48105

USA

Email: jiajiushaw@gmail.com

Received: 20 August 2016; | Revised: 08 September 2016; | Accepted: 20 September 2016

\begin{abstract}
UTL-5g is a small-molecule TNF- $\alpha$ modulator that is anti-inflammatory in a carrageenan-induced edema animal model and chemoprotective against anticancer drug-induced side effects. Recently, it was shown that UTL-5g is a prodrug and its active metabolite is 5-methylisoxazole-3-carboxylic acid (Isox). We set out to investigate the anti-inflammatory and cardioprotective effects of Isox, and two of its esterified analogues, methyl ester (Isox-Me), and ethyl ester (Isox-Et). First, the carrageenan-induced edema animal model was employed to compare their anti-inflammatory effects. Briefly, Wistar rats were randomly divided into 5 groups and pretreated with vehicle, leflunomide, Isox, Isox-Me, and Isox-Et respectively before carrageenan treatment. The results showed that the anti-inflammatory effect of Isox was essentially the same as that of leflunomide. However, the anti-inflammatory effects of Isox-Me and Isox-Et were lower than that of Isox. In the second study, cardioprotective effects of Isox, Isox-Me, and Isox-Et on doxorubicin (DOX)induced toxicity were investigated. SD rats were randomly divided into five groups. Rats in groups 1 and 2 were pretreated with vehicle; rats in groups 3-5 were pretreated with Isox, Isox-Me, and Isox-Et respectively for 5 consecutive days. One hr after the last treatment, animals in group 2-5 were treated with DOX. Twenty four hr later, effects of test compounds on cardioprotection were examined. The results showed that Isox significantly reduced the cardiotoxicity, but Isox-Me and Isox-Et did not show much cardioprotective effect. A subsequent in vitro MTT study confirmed that Isox, but not Isox-Me or Isox-Et, protected cardiomyocytes from the injury induced by DOX. In summary, Isox is anti-inflammatory against carrageenan-induced edema and the anti-inflammatory effect of Isox is at least partially responsible for its chemoprotective effect against DOX-induced cardiac injury; esterification of Isox significantly reduces its anti-inflammatory effect and cardioprotective effect.
\end{abstract}


Keywords: Isox, cardioprotective effect, doxorubicin, cardiac toxicity

Abbreviations: ALT: alanine aminotransferase; AST: aspartate aminotransferase; BNP: brain natriuretic peptide; BUN: blood urea nitrogen; CMC: carboxymethyl cellulose; DOX: doxorubicin; Isox: 5methylisoxazole-3-carboxylic acid; Isox-Et: Ethyl 5-methylisoxazole-3-carboxylate; Isox-Me: Methyl 5methylisoxazole-3-carboxylate; TNF- $\alpha$ : tumor necrosis factor alpha.

\section{Introduction}

UTL-5g (Fig. 1) is a small-molecule TNF- $\alpha$ modulator known to be anti-inflammatory and is more effective than leflunomide in a carrageenaninduced edema animal model [1]. In addition, UTL-5g is chemoprotective and radioprotective in vivo and the modulation of TNF- $\alpha$ by UTL-5g plays an important role in its protective effects [2].

Briefly, treatment of cisplatin in BDF mice elevated blood levels of liver enzymes, aspartate aminotransferase (AST) and alanine aminotransferase (ALT), as well as blood urea nitrogen (BUN) and creatinine, indicating that the liver/kidney toxicity was induced by cisplatin; cisplatin also significantly reduced platelet count in mouse blood, which indicates its myelotoxicity. Pretreatment of UTL-5g before cisplatin treatment in mice significantly lowered the elevated blood levels of AST, ALT, BUN, and creatinine; UTL-5g also significantly increased platelet count, which was significantly lowered by cisplatin. In addition, cisplatin elevated blood levels of TNF- $\alpha$; pretreatment of UTL-5g lowered TNF- $\alpha$ in a dose dependent manner, indicating that TNF- $\alpha$ plays an important role in the protective effects of UTL-5g. Overall, the results show that pretreatment of UTL-5g significantly reduces cisplatin-induced toxicity in liver, kidney, and the myeloid system [2].

Furthermore, UTL-5g was radioprotective in several animal studies. UTL-5g lowered levels of TNF- $\alpha$ (in both blood and liver) elevated by radiation and reduced the acute liver toxicity induced by localized liver irradiation [3]. In a lung radioprotection study, UTL-5g lowered levels of TNF- $\alpha$ in lung and TGF- $\beta$ in blood, both were elevated by radiation [4].

Recently, it was shown that the amide bond of UTL-5b (Fig. 1), a closely related analog of UTL-5g, was hydrolyzed by microsomes in vitro and produced two metabolites, 5methylisoxazole-3-carboxylic acid (Isox) (Fig. 1) and 2-chloroaniline (CA) [5]. Similar to UTL-5b, the amide bond of UTL-5g was later shown to be hydrolyzed to produce Isox and 2,4dichloroaniline (DCA) when treated by esterase [6]. Both Isox and DCA from the treatment of UTL-5g by human microsome were further confirmed by LC-MS/MS [7]. Furthermore, a recent study showed that UTL-5g is both an active drug and a prodrug with Isox as the active metabolite [8]; however, UTL-5g is very quickly converted into Isox in human plasma [7]. Therefore it is of interest to investigate whether Isox by itself could be a viable drug candidate.

Because Isox is a carboxylic acid, which exists as an anion under normal biological environment, it is theoretically not an ideal drug form for cell permeation. It is possible that esterification of Isox might reduce the charge density and increase the cell permeability to improve its beneficial biological effect. In this work, we set out to investigate Isox and compare with its methyl ester (Isox-Me) and its ethyl ester (Isox-Et) in (a) their anti-inflammatory effect, and (b) their cardioprotective effect. 


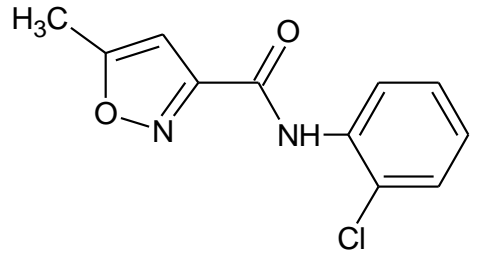

UTL-5b

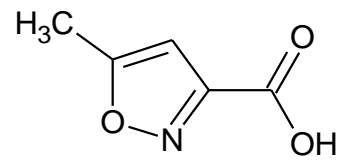

Isox

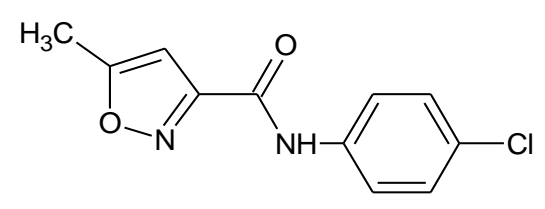

UTL-5d

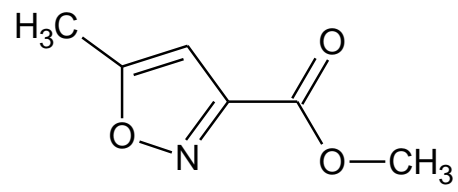

Isox-Me

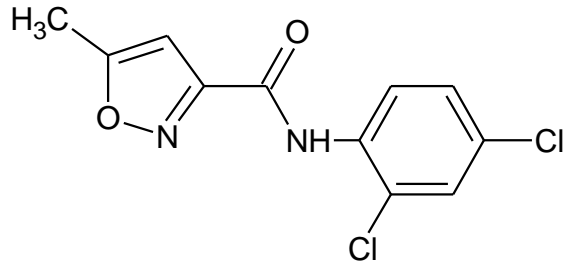

UTL-5g

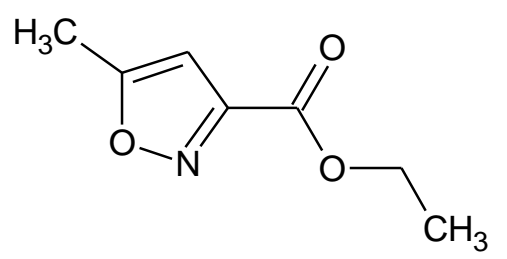

Isox-Et

Figure 1. Structures of UTL-5b, $-5 \mathrm{~d},-5 \mathrm{~g}$, Isox, Isox-Me, and Isox-Et

\section{Experimental}

\subsection{Materials}

Leflunomide, Isox, Isox-Me, and Isox-Et were purchased from Sigma (St. Louis, MO) and used without further purification. $\mathrm{H} 9 \mathrm{c} 2$ myocardiocytes were provided by Dr. Jieli Chen of Henry Ford Health System, Detroit, Michigan. High glucose DMEM and fetal bovine serum (FBS) were purchased from ThermoFisher Scientific. Male Wistar rats $(10-12$ week old, $290-330 \mathrm{~g}$ each) were purchased from Sichuan Academy of Chinese Medicine Sciences, China. Male SD rats (300-330 g ea) were purchased from Vital River Laboratory Animal Technology Co. Ltd., China. All other chemicals and reagents were purchased from Sigma unless otherwise specified.

\subsection{Carrageenan-induced paw edema}

Fifty Wistar male rats, 10 rats/group, were randomly divided into five groups one week after adaptive feeding: (1) vehicle control, (2) leflunomide (positive control), (3) Isox, (4) Isox$\mathrm{Me}$, and (5) Isox-Et. For groups 2, 3, 4, and 5, each rat was injected i.p. at $10 \mathrm{mg} / \mathrm{kg}$ respectively. One hr later, each rat was treated with $0.1 \mathrm{~mL}$ of $1 \%$ carrageenan (in saline) in the rear left footpad by subcutaneous injection. The inflammation was measured 1, 3, and 5hr afterwards. The inflammation was measured by a PV-200 Toes Volume Measuring Instrument purchased from ChengDu Technology and Market Co., Ltd.

\subsection{DOX-induced cardiac toxicity in vivo}

A total of 40 SD rats, 8 rats per group, were used. Study groups consist of: (1) vehicle control (0.5\% CMC-Na), (2) DOX, (3) Isox pretreatment then DOX, (4) Isox-Me pretreatment then DOX, and (5) Isox-Et pretreatment then DOX. Rats in groups 1 and 2 were treated with $0.5 \%$ CMC-Na and rats in group 3, 4, and 5 were treated with Isox, Isox-ME, and Isox-Et in $0.5 \% \mathrm{CMC}-\mathrm{Na}$ respectively (at $10 \mathrm{mg} / \mathrm{kg}$ ) for 5 consecutive days by i.p. injection. One hr after the last treatment, rats in groups $2,3,4$, and 5 were treated with DOX at $35 \mathrm{mg} / \mathrm{kg}$ by i.p. injection. After $24 \mathrm{hr}$, effects of test compounds were examined. Myocardial tissues were prepared for histopathologic examination and scored as 0 (normal), 1 (slightly worse), 2 (severe), and 3 (most severe) based on the degree of degeneration, fiber fracture, necrosis, and inflammation. Serum samples were tested for brain natriuretic peptide (BNP) by a commercial ELISA kit (BeiJin Fang Cheng Bai Jin Technology Co., Ltd). 


\subsection{Cardiomyocytes treated by DOX in vitro}

Briefly, myocardiocytes, H9c2 cells, were cultured in high glucose DMEM containing 10\% FBS; 10,000 cells per well of cardiomyocytes were treated by DOX with and without the 30min pretreatment of Isox, Isox-Me, and Isox-Et respectively. Percentages of viable cells were assayed by MTT assay 3 days later.

\section{Results and Discussion}

\subsection{Effects of Isox, Isox-Me, and Isox-Et on the carrageenan-induced paw edema}

As shown Table 1, the positive control (leflunomide at $10 \mathrm{mg} / \mathrm{kg}$ ) showed significant anti-inflammatory effect at all 3 time points (1, 3 , and $5 \mathrm{hr}$ ) as compared to the vehicle control. Isox also showed an anti-inflammatory effect similar to that of leflunomide at $10 \mathrm{mg} / \mathrm{kg}$. However, Isox-Me showed only limited antiinflammatory effect while Isox-Et showed virtually no anti-inflammatory effect at all. In summary, this study shows that the antiinflammatory effect of Isox is essentially the same as that of leflunomide, but the esterification of Isox, both Isox-Me and Isox-Et, appear to have reduced the beneficial biological effect.

Table 1. Carrageenan-induced edema study, $\%$ inflammation*

\begin{tabular}{|l|c|c|c|c|}
\hline & $0 \mathrm{hr}$ & $1 \mathrm{hr}$ & $3 \mathrm{hr}$ & $5 \mathrm{hr}$ \\
\hline Vehicle Control & 0 & $25.6 \pm 3.6$ & $56.6 \pm 4.4$ & $60.6 \pm 5.5$ \\
\hline Lelfunomide $(10 \mathrm{mg} / \mathrm{kg})$, inflammation & 0 & $18.2 \pm 3.6$ & $43.1 \pm 6.0$ & $52.5 \pm 6.6$ \\
\hline Isox (10 mg/kg), inflammation & 0 & $19.1 \pm 2.0$ & $47.2 \pm 1.7$ & $52.6 \pm 2.8$ \\
\hline Isox-Me (10 mg/kg), inflammation & 0 & $20.2 \pm 2.8$ & $53.5 \pm 5.0$ & $51.4 \pm 4.3$ \\
\hline Isox-Et (10 mg/kg), inflammation & 0 & $27.0 \pm 3.9$ & $58.3 \pm 4.5$ & $62.1 \pm 2.3$ \\
\hline
\end{tabular}

* \% Inflammation, average \pm Standard error, $\mathrm{n}=10$

\subsection{Cardiotoxicity induced by DOX}

Results of this cardiac toxicity study at $24 \mathrm{hr}$ after DOX treatment are described below. As shown in Table 2, compared to the vehicle control group, rats in group 2 (DOX only) showed significant cardiac toxicity as shown in heart rate, blood pressure, left ventricular systolic pressure (LVSP), left ventricular end-diastolic pressure (LVEDP), and maximum rate of left ventricular pressure change $( \pm \mathrm{dp} / \mathrm{dt}$ max $)$. With the pretreatment of Isox (group 3), all these adverse effects of DOX were lessened.

In addition, histopathology scoring results indicated that pretreatment of Isox significantly reduced the myocardial injury as compared with group 2 (DOX only) (Table 3 and Fig. 2). Histopathology scoring was measured by the following criteria: Normal myocardial tissue score 0 to worst score 3 (Severe vacuolar degeneration of myocardial cells, myocardial fiber fracture, myocardial cell necrosis, severe inflammation).

It's been reported that blood levels of BNP (also referred to as B-type natriuretic peptide) correlate with the severity and prognosis of heart failure, including left ventricular dysfunction [9, 10]. Levels of BNP are being used to diagnose heart failure, including diastolic dysfunction. As shown in Fig. 3, blood test in this study showed that BNP levels in the DOX group were much higher as compared to the vehicle control group. On the other hand, rats pretreated with Isox showed lower levels of BNP as compared to those treated with DOX only, indicating the potential cardioprotection by Isox. In the other two groups (Isox-Me and Isox-Et), no significant cardioprotective effect was observed for BNP levels. 
Table 2. DOX-induced acute cardiac toxicity

\begin{tabular}{|c|c|c|c|c|c|c|c|}
\hline Group & $\begin{array}{c}\text { Heart } \\
\text { Rate/min }\end{array}$ & $\begin{array}{c}\text { Systolic } \\
\text { Pressure } \\
(\mathrm{mm} \mathrm{Hg})\end{array}$ & $\begin{array}{c}\text { Diastolic } \\
\text { Pressure } \\
(\mathrm{mm} \mathrm{Hg})\end{array}$ & $\begin{array}{c}\text { LVSP } \\
(\mathrm{mm} \mathrm{Hg})\end{array}$ & $\begin{array}{c}\text { LVEDP } \\
(\mathrm{mm} \mathrm{Hg})\end{array}$ & $\begin{array}{c}\text { Max rate of } \\
\text { LVP change } \\
(\mathrm{dp} / \mathrm{dt} \mathrm{max})\end{array}$ & $\begin{array}{c}\text { Max rate of } \\
\text { LVP change } \\
(-\mathrm{dp} / \mathrm{dt} \mathrm{max})\end{array}$ \\
\hline Vehicle Ctrl & $434 \pm 17$ & $193 \pm 49$ & $122 \pm 37$ & $209 \pm 45$ & $-26.7 \pm 9.2$ & $11011 \pm 2546$ & $-9449 \pm 2420$ \\
\hline DOX & $389 \pm 29^{*}$ & $123 \pm 50^{*}$ & $73 \pm 30^{*}$ & $139 \pm 53^{*}$ & $-8.7 \pm 8.9 *$ & $6437 \pm 3114^{*}$ & $-5140 \pm 2931^{*}$ \\
\hline Isox + DOX & $406 \pm 42$ & $130 \pm 38$ & $82 \pm 28$ & $155 \pm 50$ & $-13.9 \pm 6.4$ & $7189 \pm 2872$ & $-5962 \pm 2346$ \\
\hline Isox-Me + DOX & $389 \pm 41$ & $120 \pm 51$ & $70 \pm 34$ & $137 \pm 67$ & $-7.03 \pm 9.7$ & $6644 \pm 3928$ & $-5333 \pm 2944$ \\
\hline Isox-Et + DOX & $393 \pm 22$ & $125 \pm 34$ & $76 \pm 19$ & $152 \pm 43$ & $-6.6 \pm 10.5$ & $8006 \pm 2926$ & $-5399 \pm 1487$ \\
\hline
\end{tabular}

* Compared to Vehicle, $\mathrm{p}<0.05 * *$ Average \pm Standard Deviation, $\mathrm{n}=8$

Table 3. Histopathology scoring results

\begin{tabular}{|l|c|c|c|c|}
\hline Group (total \# of animals) & $\begin{array}{c}\text { \# mice } \\
\text { (score of 0) }\end{array}$ & $\begin{array}{c}\text { \# mice } \\
\text { (score of 1) }\end{array}$ & $\begin{array}{c}\text { \# mice } \\
\text { (score of 2) }\end{array}$ & $\begin{array}{c}\text { \# mice } \\
\text { (score of 3) }\end{array}$ \\
\hline Vehicle control (8) & 8 & 0 & 0 & 0 \\
\hline DOX (8)* & 0 & 0 & 8 & 0 \\
\hline Isox + DOX (8)** & 0 & 7 & 1 & 0 \\
\hline Isox-Me + DOX (8) & 1 & 2 & 5 & 0 \\
\hline Isox-Et + DOX (7)*** & 0 & 2 & 5 & 0 \\
\hline
\end{tabular}

*Group 2 (DOX) compared with the vehicle control, *P $<0.01$.

$* *$ Group 3 (Isox+DOX) compared with group 2 (DOX), **P $<0.01$.

***Lower animal number due to death

In summary, pretreatment of Isox showed significant protection in DOX-induced acute cardiotoxicity, whereas it was reported that amifostine (a widely prescribed chemoprotective drug) was not cardioprotective against DOX treatment [11].

\subsection{Cardiomyocytes treated by DOX in vitro}

This in vitro study was conducted to confirm the cardioprotective effect of Isox against DOX treatment. As shown in Fig. 4, Isox, protected the
H9c2 cardiomyocytes significantly as demonstrated by MTT assay indicating that Isox is a potential cardioprotective agent for DOXinduced cardiotoxicity; this study confirms the in vivo cardioprotective effect of Isox against DOXinduced cardiotoxicity. Neither Isox-Me nor IsoxEt showed any significant protection on $\mathrm{H} 9 \mathrm{c} 2$ cells. In summary, pretreatment of the metabolite of UTL-5g, Isox, showed significant protection in DOX-induced acute cardiac toxicity. 


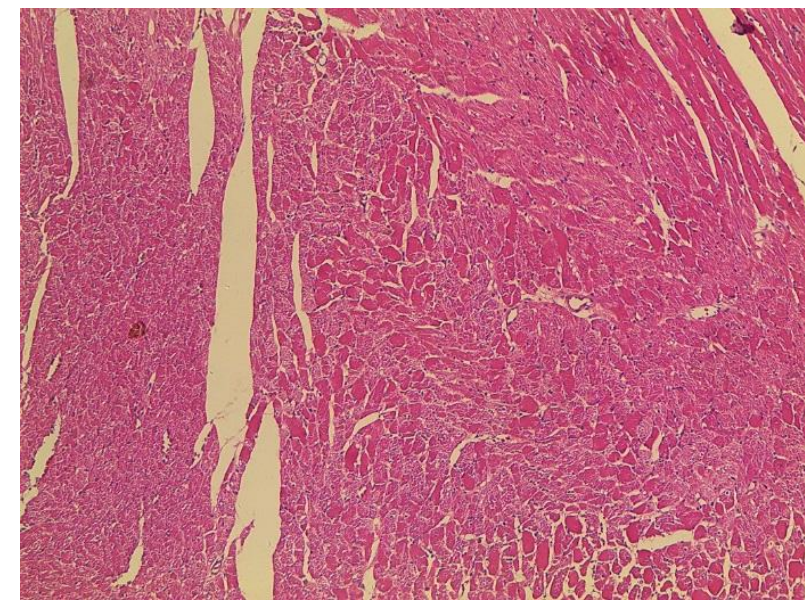

Vehicle Control

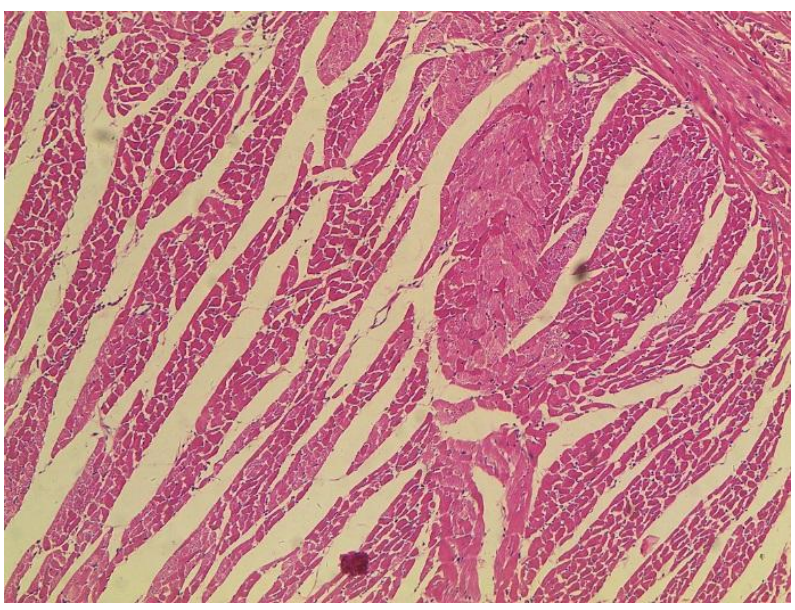

DOX only

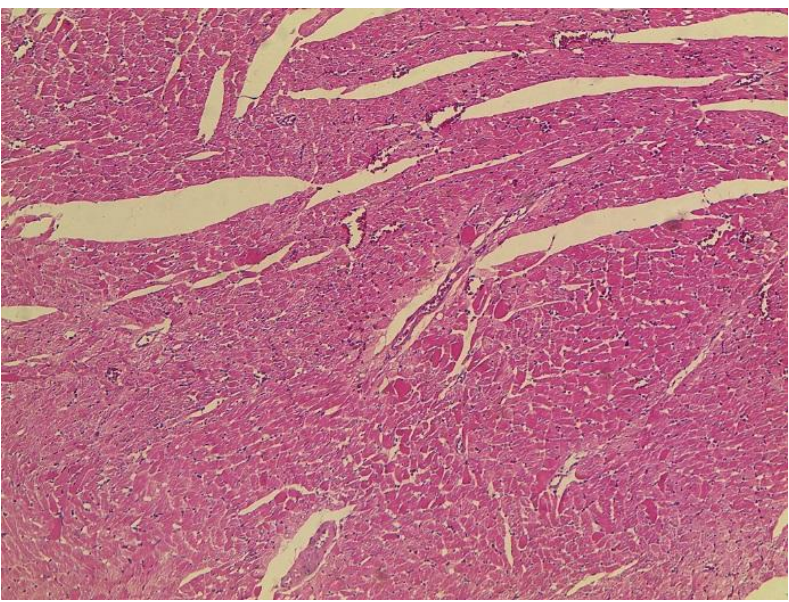

Isox + DOX

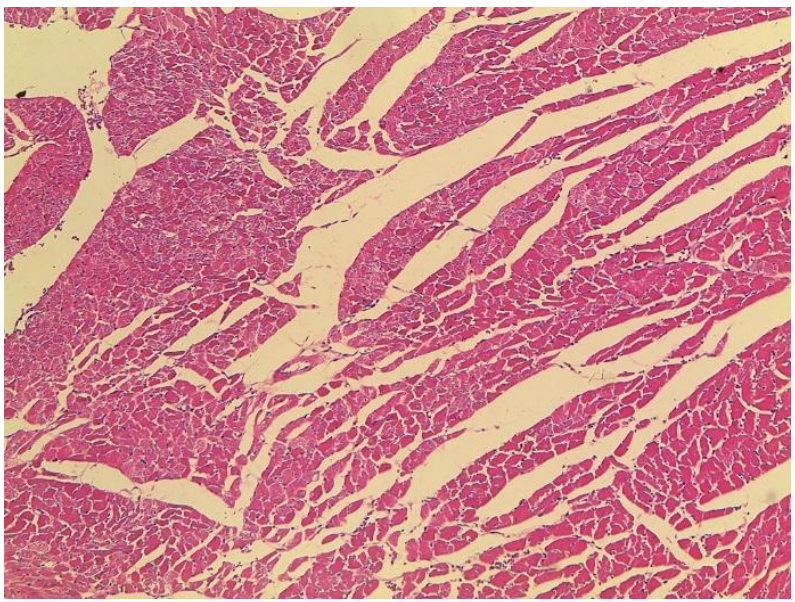

Isox-Me + DOX

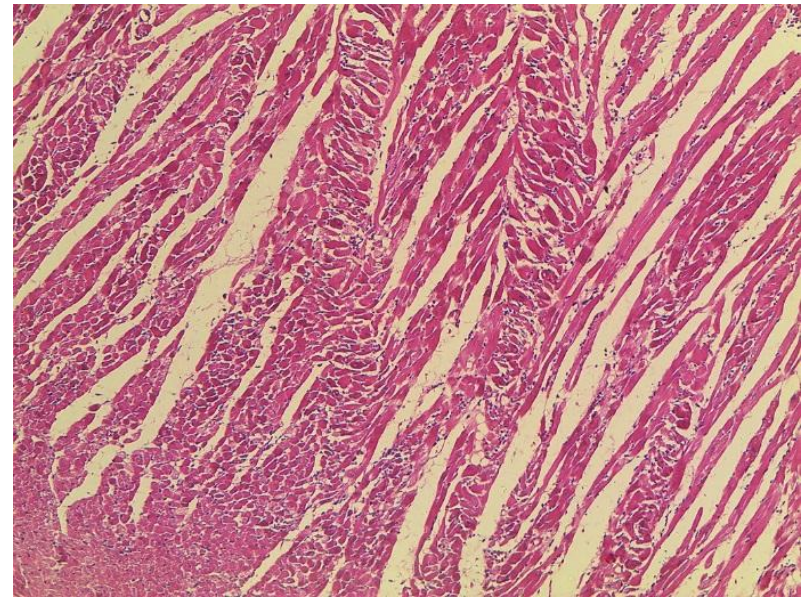

\section{Isox-Et + DOX}

Figure 2. Samples of representative pathology slides 


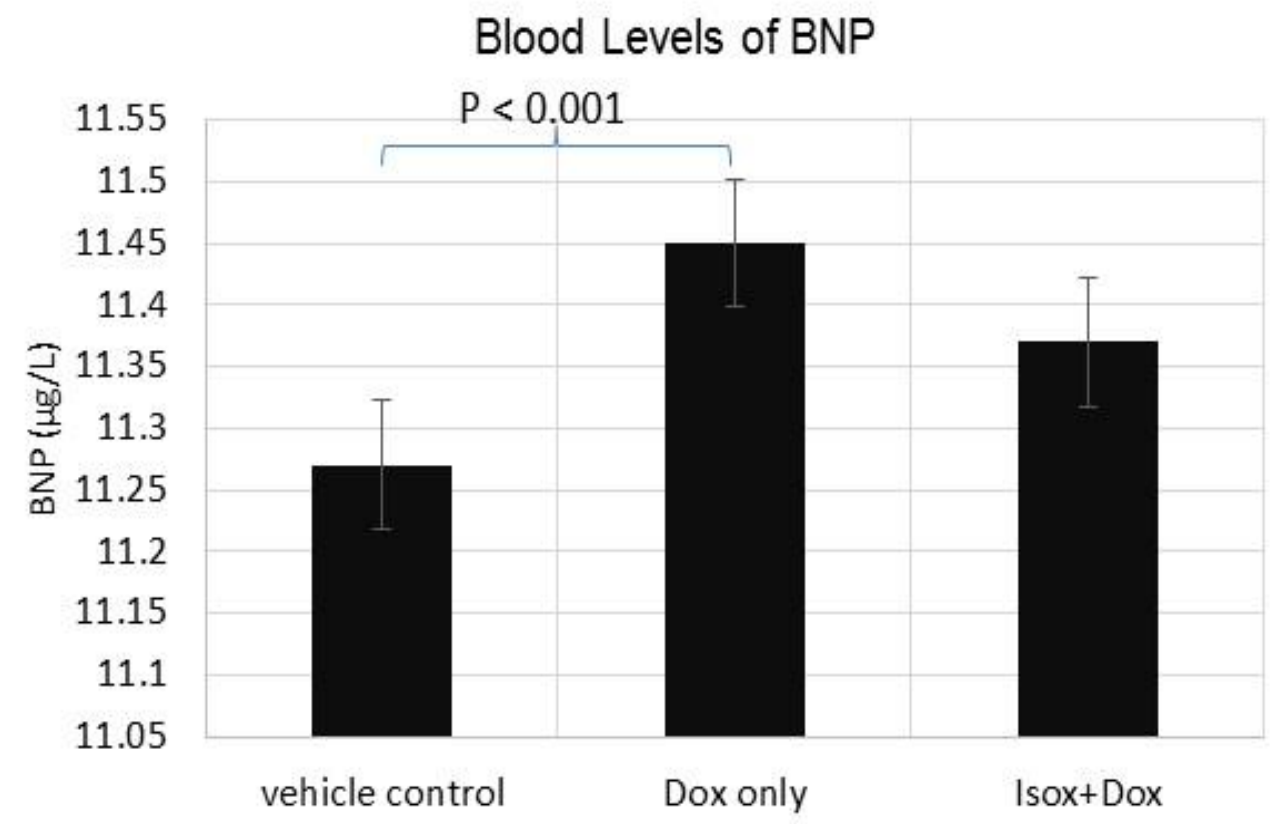

Figure 3. Blood levels of BNP after treatment of DOX with and without Isox pretreatment (Standard deviation for each group is shown)

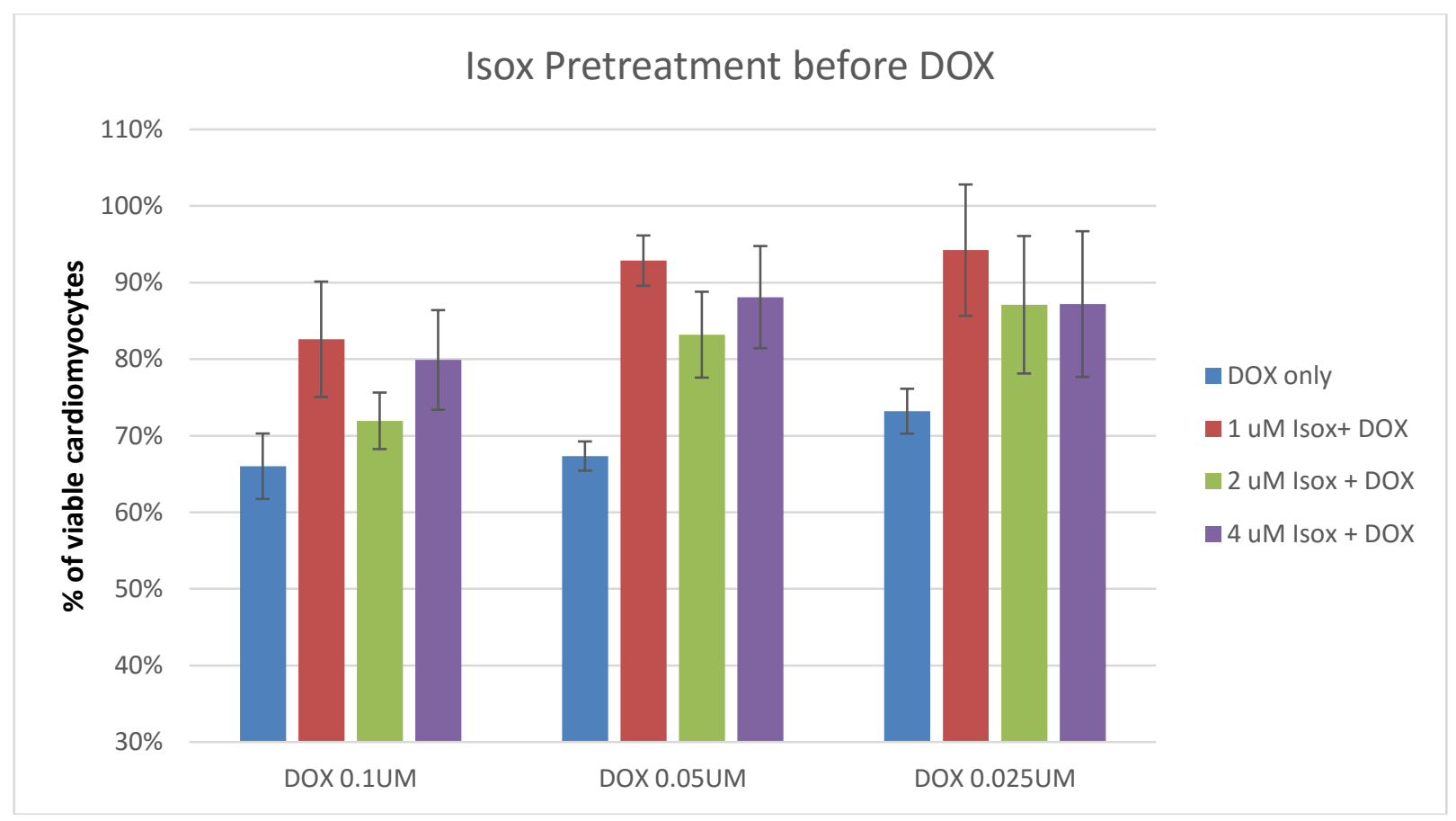

Figure 4. Percentages of viable cardiomyocytes after Isox pretreatment at different concentrations

\subsection{Summary}

DOX belongs to a group of anthracycline antibiotics and has been used for the treatment of a wide range of cancers, including solid tumor and leukemia. Its mechanisms involve intercalation of DNA and inhibition of macromolecular biosynthesis [12-14]. Similar to other chemotherapeutic agents, DOX is 
associated with a number of side effects. The most significant side effect of DOX is cardiomyopathy, which could lead to congestive heart failure. This second animal model was based on the cardiac toxicity induced by DOX.

It was somewhat surprising to find that esterification of Isox reduced the antiinflammatory effect of Isox in the carrageenaninduced edema animal model. In this case, longer alkyl chain (ethyl as compared to methyl group) did not improve the anti-inflammatory effect in the present anti-inflammatory animal study. These results indicate that cell permeation may not play a vital role in exhibiting the beneficial biological effects of Isox. Esterification in this case also showed negative impacts in the chemoprotection against DOX-induced cardiac toxicity in vivo.

Nevertheless, Isox was shown to be cardioprotective against DOX-induced side effects in vivo. To further confirm the conclusion, an in vitro study was conducted to compare the cardioprotective effect of Isox on cardiomyocytes, H9c2 cells. Again, the results showed that Isox protected cardiomyocytes from the injury induced by DOX.

Overall, this is the first time that Isox is reported to show significant protective effect in reducing the acute cardiac toxicity induced by DOX; it is at least partially due to the antiinflammatory effect, which could be partially due to the modulation of TNF- $\alpha$ [1]. Therefore, it is of great importance to continue the development of Isox as a potential cardioprotective agent.

\section{Acknowledgement}

This work was supported by a special grant from New Phiaring Bio-medical Science Co., Ltd, Chengdu, China, and a general grant from $21^{\text {st }}$ Century Therapeutics, Detroit, Michigan.

\section{References}

1. Song, Y., et al., Comparison of two molecular scaffolds, 5-methylisoxazole-3-carboxamide and 5-methylisoxazole-4-carboxamide. Curr Pharm Des, 2014. 20(1): p. 146-52. doi: 10.1124/dmd.114.060095

2. Shaw, J., et al., The small-molecule TNFalpha modulator, UTL-5g, reduces side effects induced by cisplatin and enhances the therapeutic effect of cisplatin in vivo. J Exp Ther Oncol, 2011. 9(2): p. 129-37. PMID: 21699020

3. Shaw, J., et al., Pretreatment with A SmallMolecule Tumor Necrosis Factor-Alpha (TNF- $\alpha$ ) Inhibitor, UTL-5g, Reduced Radiation-Induced Acute Liver Toxicity in Mice. AM J Biomed Sci, 2012. 4(2): p. 123131. doi: 10.5099/aj120200123

4. Brown, S., et al., UTL-5g Lowers Levels of TGF- $\beta$ and TNF- $\alpha$ Elevated by Lung Irradiation and Does Not Affect Tumorresponse to Irradiation. AM J Biomed Sci, 2014. 6(3): p. 157-165. doi: 10.5099/aj140300157

5. Shaw, J., et al., Metabolism studies of a small-molecule tumor necrosis factor-alpha (TNF-alpha) inhibitor, UTL-5b (GBL-5b). Eur J Drug Metab Pharmacokinet, 2012. 37(2): p. 83-9. DOI: 10.1007/s13318-011$\underline{0072-7}$

6. Swartz, K., et al., Using a simple HPLC approach to identify the enzymatic products of UTL-5g, a small molecule TNF- $\alpha$ inhibitor, from porcine esterase and from rabbit esterase. J Chromatogr B Analyt Technol Biomed Life Sci. 2013 Dec 1;940:1-6. doi: 10.1016/j.jchromb.2013.09.021.

7. Shaw, J., et al., A liquid chromatography with tandem mass spectrometry method for simultaneous determination of UTL-5g and its metabolites in human plasma. J Chromatogr B Analyt Technol Biomed Life Sci, 2015. 991: p. 92-8. DOI: 10.1016/j.jchromb.2015.04.015

8. Zhang, Y., et al., UTL-5g Lowers Elevated Blood Levels of TNF-a and TGF- $\beta$ and Increases Survival Rates in Animals Treated with LPS/D-(+)-galactosamine. AM J Biomed Sci, 2014. 6(2): p. 128-138. doi: 10.5099/aj140200128

9. Li, N. and J.A. Wang, Brain natriuretic peptide and optimal management of heart failure. J Zhejiang Univ Sci B, 2005. 6(9): p. 877-84. DOI: 10.1631/jzus.2005.B0877 
10. Maisel, A., B-type natriuretic peptide levels: diagnostic and prognostic in congestive heart failure: what's next? Circulation, 2002. 105(20): p. 2328-31. PMID: 12021226

11. Rigatos, S.K., et al., Investigation of doxorubicin tissue toxicity: does amifostine provide chemoprotection? An experimental study. Anticancer Res, 2002. 22(1A): p. 12934. PMID:12017274

12. Tacar, O., P. Sriamornsak, and C.R. Dass, Doxorubicin: an update on anticancer molecular action, toxicity and novel drug delivery systems. J Pharm Pharmacol, 2013. 65(2): p. 157-70. DOI: 10.1111/j.20427158.2012.01567.x

13. Fornari, F.A., et al., Interference by doxorubicin with DNA unwinding in MCF-7 breast tumor cells. Mol Pharmacol, 1994. 45(4): p. 649-56. PMID: 8183243

14. Momparler, R.L., et al., Effect of adriamycin on DNA, RNA, and protein synthesis in cellfree systems and intact cells. Cancer Res, 1976. 36(8): p. 2891-5. PMID: 1277199 